УДК 330.34:658+655

DOI: https://doi.org/10.54929/pmtl-issue1-2021-14

\title{
TRANSFORMATIONS OF PUBLIC POWER IN UKRAINE
}

\section{ТРАНСФОРМАЦІЇ ПУБЛІЧНОЇ ВЛАДИ В УКРАЇНІ}

\author{
Anastasiia Duka \\ Doctor of Economic Sciences, Professor, \\ Professor at the Department of Public Administration \\ and Organizations' Management \\ Chernihiv Polytechnic National University \\ ORCID: 0000-0001-7682-4274
}

Дука А. П. доктор економічних наук, професор профресор кафредри публічного управління та менеджменту організацій, Національний університет «Чернігівська політехніка»

The article reveals the essence of the decentralization process. It was emphasized that the establishment of Ukraine as a state governed by the rule of law presupposes the deepening of public sector reforms. It is emphasized that the current stage of state formation in Ukraine is associated with the intensive search for the optimal model of public administration. It is established that a necessary condition for the stable development of society and effective functioning is to balance national interests with the interests of residents of territorial communities, strengthening the openness and transparency of government at all levels. The main purpose of the article is to reveal the essence of transformation processes on key blocks of issues related to the nature of decentralization of power, strengthening the openness of government to the population and intensifying the fight against corruption. It is emphasized that the implementation of these blocks in the course of transformation processes in the government is embedded in the decentralization reform. Keywords: decentralization, decentralization of power, local self-government, public sector, public administration.

В статье раскрывается суть процесса децентрализации. Было подчеркнуто, что становление Украины как правового государства предполагает углубление рефрорм государственного сектора. Подчеркивается, что современный этап становления государства в Украине связан с интенсивным поиском оптимальной модели государственного управления. Установлено, что необходимым условием стабильного развития общества и эффрективного функционирования является баланс национальных интересов с интересами жителей территориальных сообществ, усиление открытости и прозрачности власти на всех уровнях. Основная цель статьи - раскрыть сущность трансфоормационных процессов по ключевым блокам вопросов, связанных с характером децентрализации власти, усилением открытости власти для населения и усилением борьбы с коррупцией. Подчеркивается, что реализация этих блоков в ходе транссрормационных процессов в правительстве должна быть заложена в реформу децентрализации. Ключевые слова: децентрализация, децентрализация власти, местное самоуправление, публичный сектор, публичная власть.

У статті розкрито сутність процесу децентралізації. Наголошено, що становлення України як правової державизумовлюєпоглибленняреформпублічногосектору. Акцентовано, щосучаснийетапдержавотворення в Україніпов'язанийз інтенсивнимпошуком оптимальноїмоделідержавного управліннякраїною. Встановлено, що необхідною умовою стабільного розвитку суспільства та ефективного фрункціонування є збалансування загальнодержавних інтересів з інтересами мешканців територіальних громад, посилення відкритості та прозорості функціонування влади на всіх ії рівнях. Основною метою статті визначено розкриття сутності трансформаційних процесів за ключовими блоками питань, які пов'язані з характером децентралізації влади, посиленням відкритості влади до населення та активізацією боротьби з корупцією. Наголошено, що реалізація цих блоків в ході трансформаційних процесів у владі закладена в рефрорму децентралізації. Проаналізовано основні практичні здобутки започаткування рефрорми децентралізації в Україні. Виявлено, що реформа органів місцевого самоврядування в Україні передбачає об'єднання (укрупнення) територіальних громад. В межах цієї рефрорми враховуються базові канони Європейської хартії місцевого самоврядування, що передбачає розгляд поняття "спроможної територіальної громади». Обгрунтовано висновок про базові передумови децентралізації публічної влади в Україні, якими є визнання, нормативне врегулювання і впровадження реформи місцевого самоврядування до правової системи держави. Акцентовано, що врахування досвіду європейських країн щодо рефоормування адміністративно-територіального устрою має велике значення для запровадження ефективної системи місцевого самоврядування в Україні. Практичне використання позитивного досвіду спроможне посилити економічну зацікавленість територіальних громад у створенні та розвитку нових виробництв, підтримці бізнесу, реалізацію програм регіонального розвитку. Ключові слова: децентралізація, децентралізація влади, місцеве самоврядування, публічний сектор, публічна влада. 
Formulation of the problem. The current stage of state formation in Ukraine is characterized by an intensive search for the optimal model of the state system of the country. This is due to the fact that a necessary condition for the stable development of society and effective functioning is to balance the national interests with the interests of the inhabitants of territorial communities, strengthening the openness and transparency of government at all levels.

The formation of Ukraine as a state governed by the rule of law presupposes the deepening of transformation processes and the deepening of public sector reforms. In addition to the traditional changes in the structure of the civil service, which in fact did not lead to a real reduction of civil servants, but changes in their status in the government, three key issues deserve special attention: decentralization of power, transparency and accessibility of public services, anti-corruption. It is the disclosure of the outlined directions of transformation in the public sector that characterizes today's processes and makes it possible to identify the potential for future results.

Analysis of recent research and publications. The problem of decentralization of power is not so new, but it is revealed differently within the framework of decentralization reform. In general, the existence of a regional structure, territorial organization of power has been widely discussed since the beginning of the formation of the basic principles of local self-government in the 90s. The main documents that generally form the foundation of the functioning of local government were the Law of Ukraine «On Local Self-Government» of 1997 [1], the «European Charter of Local Self-Government» of October 15, 1985, to which Ukraine joined on July 15, 1997 [2].

Among researchers, the issue of public sector reform is also of interest in the context of finding optimal links and interaction between local and central government in addressing community development issues. Thus, in the works of the authors Bordenyuk V., Izhak O., Tkachuk A. highlights the main specific aspects of introducing new approaches to the organization of local government, strengthening their openness, reveals the essence of the principle of subsidiarity in Ukraine. At the same time, a significant range of issues of scientific and practical nature of the problem of implementing the principles of decentralization require additional argumentation.

Formulation of the goals of the article (task statement). The main purpose of this article is to highlight the essence of the transformation process on key issues related to the nature of decentralization of power, strengthening the openness of government to the population and intensifying the fight against corruption.

Presentation of the main research material. In matters of decentralization, the main focus is on expanding the powers of local governments in addressing a number of pressing issues of territorial development. Such progress reflects the establishment of democratic governance, the transfer of power to local territorial authorities, and the provision and strengthening of citizen participation in governance at the local community level. First of all, this is manifested in the fact that decentralization covers the process of redistribution of functions, the dispersion of powers from the central government. It is worth noting that decentralization as a concept takes many forms, given the history of countries, levels of development, culture and approaches to public administration, which leads to its wide discussion by scientists, experts and the public.

The practical experience of European countries in the practical field of this issue confirms the importance of decentralization of power, which is one of the effective tools for modernizing the system of public power. In addition, the successful achievement of this creates the necessary organizational and legal prerequisites for further democratization of power relations. The idea of decentralization of public power to some extent implemented in the vast majority of developed countries. Due to decentralization in many democracies a qualitatively new level of efficiency of public power has been achieved.

At the same time, the implementation of this idea in Ukraine should be balanced and take into account the peculiarities of the development of public and state institutions that have formed in our country. In connection with the above, there is an urgent need for an in-depth analysis of European practices of decentralization of power in order to form their own national traditions of state formation at a boring stage of Ukraine's development.

The problem of decentralization of power in Ukraine is not new, but remains relevant in the context of the start of the reform in 2014 and obtaining the first results of its implementation.

In the most general sense, decentralization as a specific method of management is a process of expanding and strengthening the rights and powers of administrative-territorial units or lower bodies while narrowing the rights and powers of the center to optimize and improve the management of socially important affairs, the fullest realization of regional and local interests [3].

In the last few decades, decentralization has been a key concept in the economic development of Europe's regions. Over the years, decentralization has formed into a kind of development concept and is gradually taking new forms, taking into 
account the experience of its implementation in different countries, their historical development and geographical specifics, levels of economic and cultural development, differentiation of approaches to public administration. Given the signing of the Association Agreement between Ukraine and the European Union, special attention should be paid to the European understanding of decentralization mechanisms.

In this context, one should take into account the very forms of decentralization that have emerged in the practical sphere of its implementation. First of all, a clear distinction should be made between decentralization and deconcentration. In the case of decentralization, it is about power, competencies and resources. Deconcentration concerns only competencies.

In the case of decentralization, the process of transferring to local authorities (municipalities, councils, OTGs, etc.) certain tasks, powers and resources that belonged to the central government.

Given the peculiarities of the implementation of decentralization reform, among the main types are distinguished [3]:

- administrative (bureaucratic) decentralization. In the case of administrative decentralization, the competence of the local administrative bodies appointed by the central government, which have the right to independence from the central government, is expanded. This method of decentralization involves the introduction of the institution of governorship and in essence means the deconcentration of power;

- democratic decentralization, which provides for the creation of an extensive system of local selfgovernment, in which most local development issues are entrusted to persons elected by the population of the respective communities or regions.

In any case, changing the basic models of governance in Ukraine with an emphasis on strengthening local self-government, it is important to emphasize the problems of two areas: territorial in determining the basic level of governance at which effective governance can be provided, and financial, which provides governance.

It is the emphasis on certain areas that gives rise to political, administrative and financial decentralization. These types of decentralization in different countries are embodied in different forms and may involve different combinations, within the country and even within separate sector. The main forms of decentralization and their characteristics are presented in the figure 1 .

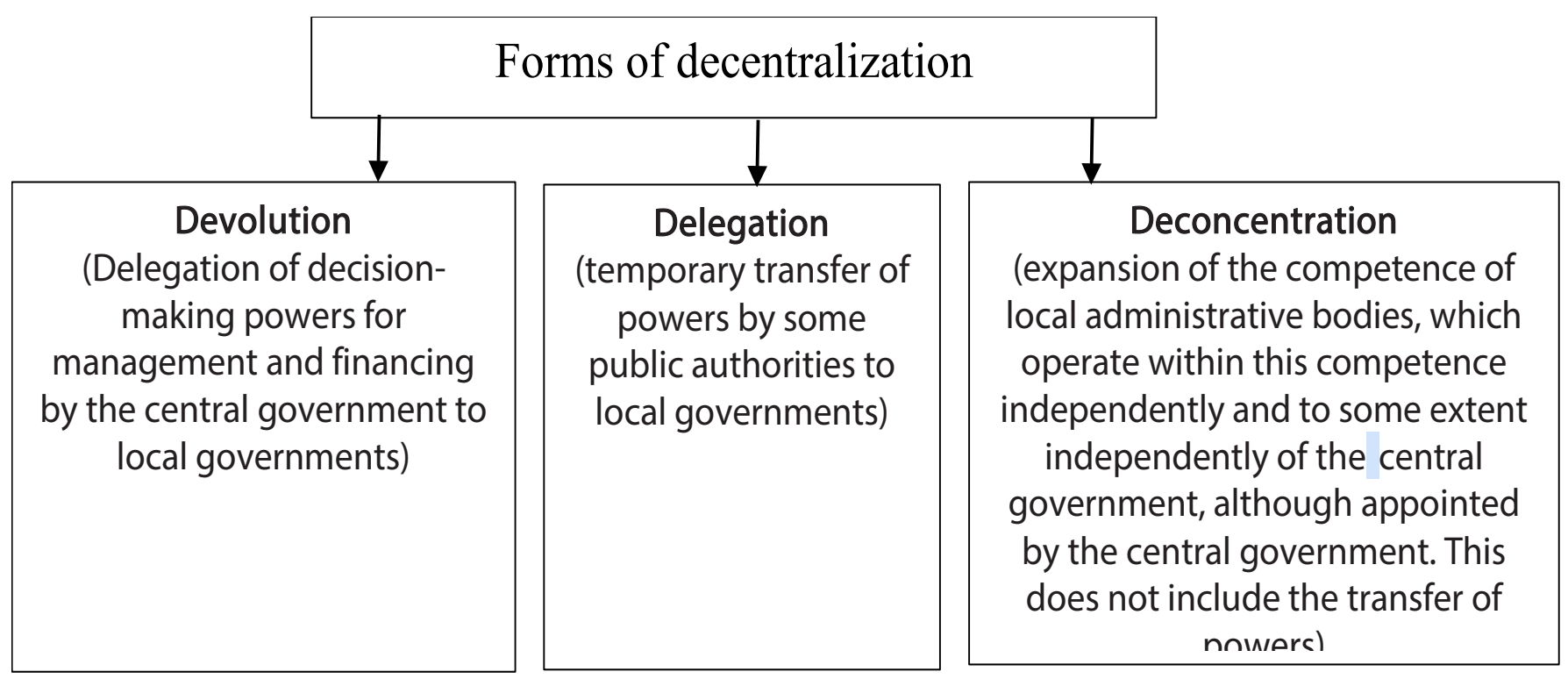

Source: systematized by the author [3]

The current stage of reform in Ukraine is characterized by the process of creating territorial communities by uniting them. In general, this process is in line with modern European trends. At the same time, with the practical experience of creating united territorial communities, the country has accumulated a number of caveats: the reduction of community influence in decision-making and the remoteness of management from residents.

The main motive for the reform, in addition to the political perspective of the issue, was to balance the goals of economic efficiency of public services and democracy at the local level, ie to increase community participation in governance. However, the increase in the size of the community, although leading to an increase in the economic benefits of the effect of scale, but is accompanied by a narrowing of the participation of residents in governance processes.

It should be noted that the processes of consolidation of the basic level of administrativeterritorial organization took place in almost all 
European countries. Thus, since 1950, the total number of local governments in Europe has decreased by almost 40 thousand. Countries such as Lithuania, Sweden and Denmark have reduced the number of local governments by $80 \%$, Britain by $77 \%$, Germany - by $50 \%$ [ 4]. The tendency to enlarge territorial units to the size that is optimal for the implementation of government social programs was initiated in the countries of Northern Europe. However, it should be borne in mind that the experience of uniting territorial communities and the impact of community size on the effectiveness of its management is a complex and ambiguous issue. First of all, each country, each territory had different starting conditions for decentralization and different strategies to achieve the goals, which must be taken into account.

On the one hand, such reforms were aimed at expanding the economic potential of local governments to implement the tasks assigned to them, and on the other - provided for the preservation and strengthening of local democracy [5]. By uniting small communities, the goals of increasing the administrative capacity and efficiency of territorial governance were achieved. At the same time, the preservation of small municipalities in European countries made it possible to achieve the goals of ensuring the relationship between residents and government, and the operational tasks of local importance - the formation of intermediate structures of inter-municipal cooperation.

According to Pavel Antkovyak, it is one of the most important features of self-government [6] there are some:

- legal provisions must protect the right of the local population (territorial community or local government) to manage «their own» affairs;

- the local community participates in the implementation of self-government on the basis of the law;

- territorial community and local self-government bodies perform public tasks within their competence;

- is based on the principles of independence (decentralization) of government;

- the introduction of a form of supervision in the activities of self-government bodies is possible only in the forms provided by law, in a way that does not violate the independence of local self-government in decision-making

Taking into account the experience of European countries in the implementation of decentralization, the following schemes of unification of territorial communities can be identified, which affected the main aspects of their size and powers:

- Northern European, within which the formation of large municipalities (Sweden, England). In Sweden, the average community size is 34 thousand inhabitants, in Denmark - 55 thousand, in
England - 120 thousand;

- Southern European, within which communities were united into small municipalities (France, Italy). In some German states, reforms have led to an increase in the average size of the municipality to 45 thousand inhabitants [7].

In most European countries, territorial reforms to significantly enlarge municipalities have been officially voluntary. However, the degree of voluntariness in reality was not very high, and territorial reforms were carried out with considerable coercion.

Usually, commissions were set up at the government level to prepare recommendations for the creation of a new format for the territorial system of local self-government. At the same time, the voluntary association of communities was realized through the adaptation of communities to the plan of the territorial structure proposed by the government. In the absence of a voluntary consensus, the decision to merge was made centrally.

The reform of local self-government bodies in Ukraine envisages the unification (consolidation) of territorial communities. This reform primarily takes into account the basic canons of the European Charter of Local Self-Government, which provides for «the right and ability of local governments to regulate and manage a significant share of public affairs within their competence in the interests of the local population» [7]. It is this aspect of the problem that involves considering the concept of «capable territorial community.» Such communities according to the current legislation are territorial communities of villages (settlements, cities) which as a result of voluntary association are capable independently or through the corresponding local government bodies to provide an adequate level of rendering of services, in particular in the field of education, culture, health care, social protection, housing and communal services, taking into account human resources, financial support and infrastructure development of the relevant administrative-territorial unit» [7].

Among the main powers that will be assigned to territorial communities as a result of the implementation of the concept of decentralization are: own and delegated powers.

Its own powers include:

- community development planning and budget formation;

- economic development, investment attraction, business development;

- management of land resources, issuance of building permits, acceptance of buildings into operation;

- development of local infrastructure;

- provision of housing and communal services;

- maintenance of streets and roads in the community; 
- organization of passenger transportation on the territory of the community;

- public safety by municipal police;

- fire protection.

Among the delegated powers are:

- social assistance through territorial centers;

- administrative services through the relevant centers for their provision;

- management of schools and kindergartens;

- primary care;

- maintenance and organization of work of houses of culture, clubs, libraries, stadiums, sports grounds

It is also worth noting that the consolidation of the territory of communities has its logical limits, as it cannot be arbitrary. The concept of forming ablebodied territorial communities stipulates that the distance from the center to the farthest settlement of the community should be such that in emergencies it can be overcome in a maximum of 30 minutes by firefighters, ambulance, police, etc. [8].

World experience gives grounds to single out the following prerequisites for its successful implementation in the system of decentralized power:

- affirmation of the principle of the rule of law;

- recognition and guarantees of local selfgovernment;

- democratic and effective election legislation;

- independence, efficiency, accessibility and transparency of the judiciary;

- perfect budget process and high financial discipline;

- availability of adequate social standards;

- developed public sector or steady trend towards its development.

Ukraine's first results in implementing decentralization reforms envisage the following main directions for change:

1) improving the legislative support of the decentralization process.

- adoption of a number of amendments to the Budget and Tax Codes of Ukraine to establish the procedure for the distribution of budget revenues between the central and local budgets;
- Law of Ukraine "On Voluntary Association of Territorial Communities" [9], which established a capable basic level of local self-government. Thus, as early as the beginning of 2017, 366 affluent united territorial communities (OTGs) were created. They included about 1,800 former local councils;

- introduction of the institute of elders in OTG, which represent the interests of rural residents in the community council. Today, more than 600 elders have been elected, and more than 1,700 are acting elders;

- Law of Ukraine «On Cooperation of Territorial Communities», within which a mechanism for solving common problems of communities: waste disposal and recycling, development of common infrastructure, etc;

- Law of Ukraine "On Amendments to Certain Legislative Acts of Ukraine Concerning Decentralization of Powers in the Sphere of Architectural and Construction Control and Improvement of Urban Development Legislation", according to which more than 90 cities and OTGs received new town-planning powers.

2) expanding the powers of local governments and optimizing the provision of administrative services. This direction made it possible to delegate to local governments the appropriate level of authority to provide basic administrative services: issuance of passport documents, registration of residence, registration of civil status, property rights, state registration of legal entities and individuals, entrepreneurs, associations, land issues. etc [10].

Conclusions. Thus, the basic prerequisites for the decentralization of public power in Ukraine are the recognition, regulation and implementation of local government reform in the legal system of the state. That is why taking into account the experience of European countries in reforming the administrative-territorial system is important for the introduction of an effective system of local selfgovernment in Ukraine, which can strengthen the economic interest of local communities in creating and developing new industries, business support, regional development programs.

\section{REFERENCES:}

1. Pro mistseve samovriaduvannia v Ukraini. Zakon Ukrainy,1997. No.280/97-BP (Verkhovna Rada Ukrayiny) [About local self-government in Ukraine. Law of Ukraine (Verkhovna Rada of Ukraine)]. Ofitsiynyy sayt Verkhovnoyi Rady Ukrayiny [The official website of the Verkhovna Rada of Ukraine]. Retrieved from https://zakon.rada.gov.ua/ laws/show/280/97-вр\#Text [in Ukrainian]

2. Yevropeiska Khartiia mistsevoho samovriaduvannia, 1985. [European Charter of Local Self-Government, 1985] Ofitsiynyy sayt Verkhovnoyi Rady Ukrayiny [The official website of the Verkhovna Rada of Ukraine]. Retrieved from https://zakon.rada.gov.ua/laws/show/994_036\#Text [in Ukrainian]

3. Detsentralizatsiia ta efektyvne mistseve samovriaduvannia: navch. posibnyk dlia posadovtsiv mistsevykh ta rehionalnykh orhaniv vlady ta fakhivtsiv z rozvytku mistsevoho samovriaduvannia [Decentralization and effective local self-government: textbook. a guide for local and regional government officials and local government development professionals]. 2007. Kyiv: PROON/ MPVSR [in Ukrainian]

4. Bordeniuk, V. I. (2007). Mistseve samovriaduvannia ta derzhavne upravlinnia: konstytutsiino-pravovi osnovy 
spivvidnoshennia ta vzaiemodii: monohr. [Local self-government and public administration: constitutional and legal bases of correlation and interaction: monograph]. Kyiv : Parlam vyd-vo [in Ukrainian]

5. Yizhak, O. Pryntsyp subsydiarnosti YeS i mezhi yoho zastosuvannia v Ukraini [The principle of EU subsidiarity and the limits of its application in Ukraine]. Retrieved from : http://db.niss.gov.ua/ docs/polmil/185.htm [in Ukrainian]

6. Paweł Antkowiak. Decentralizacja władzy publicznej w Polsce na przykadzie samorządu terytorialnego Retrieved from : https://repozytorium.amu.edu.pl/bitstream/10593/4046/1/Pawe\%C5\%82\%20Antkowiak\%20-\%20 Decentralizacja\%20w\%C5\%82adzy\%20publicznej\%20w\%20 Polsce.pdf (in Poland)

7. Tkachuk, A. (2012). Mistseve samovriaduvannia ta detsentralizatsiia: prakt. posib. [Local self-government and decentralization: practice. way.]; Shveitsarsko-ukrainskyi proekt «Pidtrymka detsentralizatsii v Ukraini. DESPRO». Kyiv : TOV «Sofiia» [in Ukrainian]

8. Sut reformy orhaniv mistsevoho samovriaduvannia (detsentralizatsii) [The essence of local government reform (decentralization)] Retrieved from: http://icps.com.ua/assets/uploads/images/files/verstka_decentralizaciya.pdf [in Ukrainian]

9. Pro dobrovilne obiednannia terytorialnykh hromad. Zakon Ukrainy 2015, № 157-VIII. [About voluntary association of territorial communities. Law of Ukraine 2015] Ofitsiynyy sayt Verkhovnoyi Rady Ukrayiny [The official website of the Verkhovna Rada of Ukraine]. Retrieved from https://zakon.rada.gov.ua/laws/show/157-19\#Text [in Ukrainian]

10. Derzhavna polityka, zakonodavchi napratsiuvannia, promizhni rezultaty pershoho etapu detsentralizatsii vlady $\checkmark$ Ukraini [State policy, legislative developments, intermediate results of the first stage of decentralization of power in Ukraine]. Retrieved from: http://decentralization.gov.ua/about [in Ukrainian]. 